\title{
SERVICE QUALITY AND CUSTOMER SATISFACTION: A COMPARATIVE STUDY OF AN INDIAN PUBLIC VS PRIVATE BANK
}

\author{
DHARMENDRA SINGH \\ American University of Ras Al Khaimah \\ United Arab Emirates
}

\begin{abstract}
This study focuses on the service quality and customer satisfaction among the private and public sector banks in India. Today customers are supposed to have awareness about the financial services provided by the banking sector. An attempt has therefore, been made in this paper to quantify the 'awareness level' of the customers and analyze the 'service quality experience' of the customers from their banks. The study has been carried out to compare the service quality experienced by customers of the public and private sector banks and to study the link between service quality and customer satisfaction. For that reason a well structured questionnaire was used to collect the views of customers on various service dimensions and the satisfaction of the customers regarding the services offered by the public and private sector banks. Various statistical tools like ANOVA, Factor Analysis and Multiple Regressions were used for analyzing the data collected on five service dimensions of SERVQUAL and satisfaction of customers. The results indicate that the private sector bank was better in terms of providing services and creating awareness about their products and services. The study also proves that an increase in service quality will most likely lead to customer satisfaction.
\end{abstract}

Keywords: Banking sector, customer satisfaction, service quality, awareness.

\section{Introduction}

The banking system in India has different features as compared to other parts of the world. The reason being its diverse culture, wide disparity in the income and education level of the country. There is a large percentage of uneducated population but, at the same time, the country has a large pool of managerial and technologicallyadvanced talents.

The entry of information technology into the banking sector has replaced traditional banking methods with the innovative customer-friendly services. The different services such as ATMcum debit cards, credit cards, i-banking, phone banking, and mobile banking have changed the face of Indian banking. These services provide anywhere and anytime cash withdrawal/depositfacilities, quick remittances ,fast transfer of funds and bill collections and fast screening of credit proposals without undue paper work etc. Private banks have taken a lead in attracting the customers and capturing the semi-urban and urban areas of India. These changes have promoted public commercial banks to design world-class customer service systems and practices to meet the growing customer needs.

There is a cut-throat competition between the Indian public and private sector banks to cater to the upcoming demands of the customers. It is not 
only to attract new customers but also to place emphasis on retaining the existing customers which is only possible by providing quality services to the customers. Therefore the focus should be on providing better customer services to the customers of the public and private sector banks in India.

\section{An Overview of the Indian Banking Sector}

The Indian banking sector is quite complex. It consists of public sector banks, old private banks, new private banks and foreign banks (Banerjee, 2005). While the importance of the public sector banks has declined in recent years, they still dominate banking activities. The commercial banking segment comprises 28 public sector banks, in which the government has a majority ownership of over 51 per cent. There are 24 other commercial banks and 29 foreign banks. The Reserve Bank of India (RBI), the central bank, is responsible for the control and operations of banks, including managing the money supply. The Bank Nationalization Act of 1980, named as the Banking Companies (Acquisition and Transfer of Undertaking) Act, 1980, specifies that the Indian government's equity in the nationalized banks cannot be below 51 per cent. The Act also restricts foreign financial institutions at 24 per cent of the number of total banks. This governmental control apparently brought the banks under constant governmental scrutiny and led to a high degree of under lending (Chakrabarti, 2005). Indian banking was subjected to tighter governmental control over the ownership from the late 1960s. This was known as social control over banks; the government nationalized the banks later. The banks were subjected to directed credit, prescribed interest rates, and substantial pre-emption of deposits (Sathye, 2003). Prior to 1991, Indian banking was dominated by government-owned banks (public sector banks). These banks controlled over 90 per cent of the banking sector assets. However, most of these banks were inadequately capitalized.
A number of reasons make the banking sector in India an exciting case to study. In the 1990s, India experienced liberalization of the banking sector with the objective of enhancing efficiency, and profitability. Second, the banking sector had undergone an important change, driven by the need for creating a market-driven, productive, and competitive economy in order to support higher investment levels and emphasize growth. Interest rate deregulation was perceived as the cornerstone of the banking sector liberalization in India. From a completely governmentdetermined interest rate structure, Indian banks have gradually moved to an almost entirely market-driven interest rate system (Chakrabarti, 2005). The importance of competition has also been recognized by the RBI and laws are now encouraging the entry of new private sector banks, and more trouble-free entry of branches of foreign banks in India.

\section{Objectives of the Study}

1. To evaluate and compare the quality of banking services of the public and private sector banks.

2. To measure the awareness level of the bank customers.

3. To measure the relationship between service quality and customer satisfaction

\section{Review of Literature}

Numerous studies were carried out by the different researchers in India and abroad to find out the dimensions and factors, which influence the banking services. The literature available on service quality suggests that two schools of thought dominate the existing thinking. One is the Nordic school of thought based on Gronroos (1984) two-dimensional model and the other is the North American school of thought based on Parasuraman et al. (1988) fivedimensional SERVQUAL model. Considering other major conceptual and empirical works in 
the area, it appears that service quality covers: (a) Customers' experiences with the tangibles, reliability, responsiveness, assurance, and empathy aspects of the services delivered by a firm (Parasuraman et al., 1988); (b) technical and functional quality (Gronroos, 1984); (c) service product, service environment, and service delivery (Rust \& Oliver, 1994); and (d) interaction quality, physical environment quality, and outcome quality (Brady \& Cronin, 2001).

SERVQUAL was criticized by Cronin and Taylor (1994) and Mc Alexander et al. (1994). They revealed the importance of the SERVPERF scale to measure service quality. Naceur Jabnoun et al. (2003) developed a modified SERVQUAL for measuring service quality in the United Arab Emirates commercial banks. The instrument included thirty items that belonged to the five dimensions of SERVQUAL. The developed instrument was tested for reliability and validity and the result indicated that the instruments had only three dimensions.

Seth and Deshmukh (2005) analyzed service quality models and concluded that customer expectation was changed by elements such as time, interaction with particular levels of service quality and competitive environment. Similarly, Carlo et al. (2005) presented a framework focusing on the quality of the banking services, resulting in the creation of five elements (customer relationship, business transactions, information technology, branch and its image) which could lead to quality in services targeting customer satisfaction. In addition, Bhat (2005) in his comparative study of service quality perceptions in public sector banks, private sector banks and foreign banks in North India concluded that customer's perception about the service quality of the banks was below their expectations for all the banks.

Researchers have also validated the link between service quality and customer satisfaction. As service quality improves, the probability of customer satisfaction increases. In this way, the association between service quality and customer satisfaction has emerged as a topic of critical and strategic concern (e.g. Bolton \& Drew, 1991; Cronin \& Taylor, 1992; Taylor \& Baker, 1994). Mihelis (2001) evaluates customer satisfaction only in the private sector banks in Greece. The methodology of the paper was based on the principle of multi-criteria analysis and preference disaggregating modelling. The results are focused on the determination of the significant service dimensions and the segmentation to customer clusters with distinctive preferences and expectations.

Sultan Singh (2008) in his study, found out that the level of customer service and satisfaction was influenced by factors such as the location of the branch and lay out, differentiated services, systems and procedures, delegation and decentralization, mechanization and computerization, complaint redressal, skills, attitudes and responses of the employees.

Aruna Dhade and Manish Mittal (2008) observed that the customers of private banks were highly satisfied compared to the customers of the SBI. Customers of the SBI were dissatisfied with regard to the processing time taken for account handling and technological updates and made the customers to shift to another bank, while in the case of the private bank's customers, proximity to residence and sometimes delay in the processing time could be the likely reasons to change the existing bank with a new one.

Saneyei Ali (2008) examined the nature of relationships between service quality and customer satisfaction in the Iranian banking system. Findings of the study showed that tangibles, reliability and empathy were significant predictors of customer satisfaction but ignored the technological factors of the banking services. The study concluded that service quality was at the root of customer satisfaction and was linked to such behavioural outcomes as customer loyalty. 
Kazi Omar Siddiqi (2011) studied the interrelationships between service quality attributes, customer satisfaction and customer loyalty in the retail banking sector in Bangladesh. The study was required to discover the most important attributes in bank settings, which may be used to assess the characteristics of the banks as experienced by customers. This study suggested that SERVQUAL was a suitable instrument for measuring the bank service quality in Bangladesh.

Ravichandran et al. (2010) studied the influence of service quality on customer satisfaction using the SERVQUAL model on the Indian retail banking sector. They considered additional three extra variables in addition to the original SERVQUAL scale. The variables were service charge charged by the bank, interest rate and customer complaint-handling system as suggested by researchers like Bahia \& Nantel, (2000); and Suresh Chander et al. (2002). The results of this study suggested that recognizing responsiveness as another form of responsibility was essential to every customer of the banking system in order to increase customers' overall satisfaction with the banking service.

Popli and Rao (2009) studied relationship marketing in Indian banks and revealed that Private sector banks have been able to execute the relationship marketing practices more effectively as compared to the public sector banks. They also observed that responsiveness and empathy of both the public as well as the private sector banks scored the least. However, a micro analysis revealed that the public sector banks had the highest scores in terms of reliability and assurance whereas the private sector banks fared better in terms of tangibility, reliability and assurance. Moreover, Saravanan \& Rao (2007) proved that customer satisfaction was based on the level of service quality delivered by the service providers and also customer satisfaction was determined by the consumer's cumulative experience with the company. Therefore, the existing literature supports that there is a link between service quality and customer satisfaction.

\section{Research Design}

The research design adopted for the study was descriptive in nature and the research was conducted in two stages. In first the stage, the researcher reviewed the literature to get an indepth understanding of the various aspects of the study. After that, informal discussions and interviews were conducted with a small group of bank employees. This literature study and the interviews helped the researcher to formulate a conceptual framework in the form of a questionnaire.

In the second stage, the questionnaire was tested on some sample bank customers. The feedback received during the testing helped in controlling the response bias and increased the reliability of the final questionnaire. After that, the final questionnaires were used for the data collection.

\section{Selection of Banks \& Data Collection Methodology}

From the nationalized banks, the State Bank of India (SBI) was chosen because of its large network of branches and customer base in India. At present, the State Bank of India is the largest commercial bank of India and is ranked one of the top five banks worldwide. It serves 90 million customers through a network of 11,448 branches. For the private banks the Housing Development Finance Corporation (HDFC) Bank was chosen. Because it was the first 'inprinciple' private sector bank in India which also introduced intelligent banking in India. These two sample banks have a strong retail presence and offer a wide range of services for their customers. These banks have also taken initiatives to satisfy their customers and provide value-added services

The survey was carried out on a sample size of 400 customers associated with either the SBI or the HDFC Bank across India which was further divided into 4 groups of 100 customers from 
each region of India i.e. North, South, East and West.

\section{Pre-Testing of the Questionnaire}

The questionnaire was pre-tested with the response obtained from 40 respondents. Results of the reliability tests resulted in an overall Cronbach alpha value of 0.84 . The feedback of the respondents was useful in carrying out a few modifications in the items included earlier in the questionnaire. The final questionnaire was again subjected to a reliability test and the same resulted in an improvement with the alpha value of 0.95 , thus further confirming that the instrument was fully reliable and internally consistent.

To identify and analyse the level of awareness and customer satisfaction, 20 variables were identified based on the pilot study and previous studies. These 20 items included every facility and services offered to customers like efficient and speedy services, longer working hours, bank reputation, innovative services offered by bank, convenient location, acquaintance with bank officials, web-based services, payment of utility bills, etc. The opinion of 200 customers each from a public and a private bank were measured on the above-mentioned variables on a seven-point scale ranging from 7 to 1 depending on the importance attached to each reason. For example, 'Highly satisfied' was ranked 7, 'Neither satisfied nor dissatisfied' with value of 4 , and 'Highly dissatisfied' with 1 .

\section{Respondents Profile}

Previous studies on customer satisfaction and service quality have shown the demographic profiles of the respondents to be one of the major factors that influence the adoption/non-adoption of technology-based products and services of the banks like ATM, i-Banking, m-Banking. It has always been argued that there are demographic differences between the users and non-users of these services. It is often found that the younger generation is generally more computer literate and has an attraction for the web and are more likely to adopt these technological services. Thus, the demographic characteristics of the users among the sample respondents were analysed and the results are shown in Table 1.

Table 1

Demographic Characteristics of Respondents

\begin{tabular}{|c|c|c|c|c|}
\hline \multirow[t]{2}{*}{ Bank } & \multicolumn{2}{|c|}{ PUBSB } & \multicolumn{2}{|c|}{ PVTSB } \\
\hline & Male & Female & Male & Female \\
\hline Below 30 & 30 & 15 & 33 & 19 \\
\hline 31 to 45 & 58 & 29 & 69 & 28 \\
\hline 46 to 60 & 31 & 26 & 24 & 18 \\
\hline Above 60 & 11 & - & 09 & - \\
\hline Total & 130 & 70 & 135 & 65 \\
\hline
\end{tabular}




\begin{tabular}{lcc}
\hline Income/Month & PUBSB & PVTBS \\
\hline Rs 10,000 or below & 70 & 34 \\
Rs 10,001-Rs 20,000 & 48 & 72 \\
Rs 20,001-Rs 30,000 & 22 & 24 \\
Rs 30,001-Rs 40,000 & 32 & 41 \\
Above Rs 40,000 & 28 & 29 \\
\hline Total & 200 & 200 \\
\hline & & PVTBS \\
\hline Education & PUBSB & 23 \\
\hline Undergraduates & 18 & 112 \\
Graduates & 133 & 46 \\
Postgraduates & 35 & 19 \\
Professional qualification & 14 & 200 \\
\hline Total & 200 & \\
\hline
\end{tabular}

Acronyms. PUBSB: Public Sector Bank, PVTSB: Private Sector Bank.

The demographic characteristics of the respondents in Table 1 indicate that the majority of the respondents of the pubic as well as the private sector bank belong to the 30 to 45 -age group, followed by 46-60-age group. On the income level, private bank customers' income slab was high as compared to public sector bank customers. The majority of the respondents belong to the Rs 10,001 to Rs 20,001 income group. Furthermore, the majority of the graduate and postgraduate respondents were in the private sector bank as compared to the public sector bank. Thus it was clear that respondents of the private sector bank had higher education qualifications as compared to the public sector bank respondents.

\section{Awareness of Technological Services}

Respondents were asked about their awareness of the technological services provided by their bank. The responses about their awareness are given in the Table 2.

In PUBSB \& PVTSB, ATM was the highly known service which was known to all the respondents of each category except for a very few retired respondents of PUBSB belonging to the eastern region. For the i-banking service of PUBSB, $78 \%$ of service-class, $67 \%$ of businessclass customers were aware of this service. On the other side for PVTSB, the awareness level of i-banking among the business-class as well as the service-class was around $95 \%$.

Regarding phone the banking service of PUBSB, $80 \%$ service-class and $67 \%$ business-class customers were aware about this service. While in PVTSB $98 \%$ of serviceclass and $93 \%$ of business-class customers were aware of this service. For the mobile banking service of PUBSB, 23\% of service-class and $41 \%$ of business-class customers were aware of 
Table 2

Awareness Level of Technological Services

\begin{tabular}{|c|c|c|c|c|c|}
\hline \multirow[t]{2}{*}{ Services } & \multirow[t]{2}{*}{ Occupation } & \multicolumn{2}{|l|}{ PUBSB } & \multicolumn{2}{|l|}{ PVTSB } \\
\hline & & Yes & No & Yes & No \\
\hline \multirow{5}{*}{ ATM } & Service & $100(100 \%)$ & -- & $100(100 \%)$ & -- \\
\hline & Business & $60(100 \%)$ & -- & $60(100 \%)$ & -- \\
\hline & Student & $20(100 \%)$ & -- & $20(100 \%)$ & -- \\
\hline & Retired & $18(90 \%)$ & $2(10 \%)$ & $20(100 \%)$ & -- \\
\hline & Aggregate & 198(99\%) & $2(1 \%)$ & $200(100 \%)$ & -- \\
\hline \multirow{5}{*}{ i-Banking } & Service & $78(78 \%)$ & $22(22 \%)$ & $95(95 \%)$ & $5(5 \%)$ \\
\hline & Business & $40(67 \%)$ & $20(33 \%)$ & $55(92 \%)$ & $5(8 \%)$ \\
\hline & Student & $20(100 \%)$ & -- & $20(100 \%)$ & -- \\
\hline & Retired & $7(35 \%)$ & $13(65 \%)$ & $10(50 \%)$ & $10(50 \%)$ \\
\hline & Aggregate & $145(73 \%)$ & $55(27 \%)$ & $180(90 \%)$ & $20(10 \%)$ \\
\hline \multirow{5}{*}{ Phone banking } & Service & $80(80 \%)$ & $20(20 \%)$ & $98(98 \%)$ & $2(2 \%)$ \\
\hline & Business & $40(67 \%)$ & $20(33 \%)$ & $56(93 \%)$ & $4(7 \%)$ \\
\hline & Student & $20(100 \%)$ & -- & $20(100 \%)$ & -- \\
\hline & Retired & $4(20 \%)$ & $16(80 \%)$ & $10(50 \%)$ & $10(50 \%)$ \\
\hline & Aggregate & $144(72 \%)$ & $56(28 \%)$ & $184(92 \%)$ & $16(8 \%)$ \\
\hline \multirow{5}{*}{ Mobile banking } & Service & $23(23 \%)$ & $77(77 \%)$ & $71(71 \%)$ & $29(29 \%)$ \\
\hline & Business & $25(41 \%)$ & $35(59 \%)$ & $46(76 \%)$ & $14(24 \%)$ \\
\hline & Student & $7(35 \%)$ & $13(65 \%)$ & $16(80 \%)$ & $4(20 \%)$ \\
\hline & Retired & -- & $20(100 \%)$ & -- & $20(100 \%)$ \\
\hline & Aggregate & $55(27 \%)$ & $145(73 \%)$ & $133(66 \%)$ & $67(34 \%)$ \\
\hline \multirow{5}{*}{ Plastic-money (Credit card) } & Service & $94(94 \%)$ & $6(6 \%)$ & $98(98 \%)$ & $2(2 \%)$ \\
\hline & Business & $60(100 \%)$ & -- & $60(100 \%)$ & -- \\
\hline & Student & $20(100 \%)$ & -- & $20(100 \%)$ & -- \\
\hline & Retired & $5(25 \%)$ & $15(75 \%)$ & $6(30 \%)$ & $14(70 \%)$ \\
\hline & Aggregate & $179(89 \%)$ & $21(11 \%)$ & $184(92 \%)$ & $16(8 \%)$ \\
\hline
\end{tabular}

Note: Values in parenthesis indicate percentage of the respective occupation category sample and the awareness of the respondents. 
this service. On the other side in PVTSB 71\% service-class and $76 \%$ business-class customers were aware of the same service. However, regarding the awareness level of the plasticmoney service in PUBSB, 94\% service-class and all the respondents of the business class were aware. In the case of PVTSB almost all the respondents were aware of this service. Table 2 also reveals that all the respondents belonging to the student category of PUBSB and PVTSB were highly aware of these services while the awareness level among the retired persons was low in both the banks.

Table 3 shows the results of the test about the population proportion for the two samples. The level of significance was is considered to be .01 and a two-tail test was conducted to test the significance of the difference between the awareness level of the respondents from PUBSB and PVTSB. The test was conducted separately for the different sets of services like ATM, i-banking etc.

Table 3

Difference in Awareness Level (Z-Test)

\begin{tabular}{lccl}
\hline \multicolumn{1}{c}{ Services } & Z Value & $\begin{array}{c}\text { Critical Z Value } \\
(\alpha=.01)\end{array}$ & \multicolumn{1}{c}{ Decision } \\
\hline ATM & 1.41 & 2.58 & No significant difference \\
i-Banking & 4.37 & 2.58 & $\begin{array}{l}\text { Significant difference in } \\
\text { awareness level }\end{array}$ \\
Phone banking & 5.26 & 2.58 & $\begin{array}{l}\text { Significant difference in } \\
\text { awareness level }\end{array}$ \\
Mobile banking & 7.8 & 2.58 & $\begin{array}{l}\text { Significant difference in } \\
\text { awareness level }\end{array}$ \\
& 1.035 & 2.58 & No significant difference \\
\hline
\end{tabular}

The test concludes that the awareness level for services like internet banking, phone banking and mobile banking are significantly different for the two sets of consumers; for ATMs and plastic money there is no significant difference between the two sets of consumers.

\section{Measure of SERVQUAL Service Dimensions}

Table 4 shows the average responses for the banks on the seven-point scale for the five service dimensions i.e. reliability, responsiveness, tangibles, assurance and empathy. In the case of the private sector bank (PVTBS) the scores for 'tangibility' were the highest whereas in the case of the public sector bank (PUBSB) the scores for 'reliability' were the highest. 'Empathy' was the dimension which was relatively ignored by both the banks. The results were consistent with the study of Popli G. S. and Rao D. N. (2009).

Table 4 also reveals that under the "assurance" dimensions, the two variables "employees are consistently courteous" and "employees have the knowledge to answer customers' queries" were the highly-rated variables in both the public and the private banks but the private bank customers were more satisfied with the quality 
of the services. Similarly, in the "tangible" dimension the two variables "employees having a neat and professional appearance" and "physical ambience of the office are up to the mark" were highly rated variables for both the public and the private banks but the quality of service favoured was in the private bank as compared to the public bank.

Table 4

Responses on SERVQUAL Service Dimensions

\begin{tabular}{lcc}
\hline \multicolumn{1}{c}{ Service Quality Dimensions } & PUBSB & PVTSB \\
\hline Reliability & 4.88 & 5.05 \\
Sincere in solving the problem & 5.06 & 5.18 \\
Providing service as promised & 4.74 & 4.85 \\
Maintaining error-free record & 4.74 & 4.97 \\
Providing service at the promised time & 4.99 & 5.19 \\
Responsiveness & 4.15 & 4.18 \\
Providing prompt service to customers & 4.21 & 4.00 \\
Willing to help customers & 4.13 & 4.19 \\
Keeping customers informed about the services & 4.08 & 4.33 \\
Always ready to respond to customer's request & 4.18 & 4.21 \\
Tangible & 4.86 & 5.19 \\
Employees having a neat and professional appearance & 5.02 & 5.34 \\
Site of the office is perfect & 4.97 & 5.29 \\
Physical ambience of the office are up to the mark & 5.06 & 5.63 \\
Overall impression of the office is satisfactory & 4.37 & 4.50 \\
Assurance & 4.69 & 5.12 \\
Employees instill confidence in customers & 4.64 & 4.90 \\
Customers feel comfortable interacting with banks & 4.63 & 4.92 \\
Employees are consistently courteous & 4.91 & 5.54 \\
Employees can solve customers' queries & 4.59 & 5.12 \\
Empathy & & \\
Employees give individual attention & 4.04 & 4.05 \\
Employees understand the needs of the customers & 3.99 & 3.91 \\
Bank's working hours are convenient to customers & 4.02 & 3.93 \\
Employees have the customer's best interest at heart & 4.10 & 4.13 \\
\hline
\end{tabular}

Table 5, shows the results of the one-way ANOVA done to test the difference between the mean values of the service quality dimensions for the two banks belonging to the public sector and the private sector. The test was done at the $5 \%$ level of significance. According to the results p-value is was less than .05 for the three dimensions - reliability, tangibility and assurance. Therefore, this indicated that there was a significant difference between the mean values for the above-mentioned service dimensions. The private sector bank was better than the 
public sector bank in three service dimensions;

difference between the two sector banks ( $\mathrm{p}$ value reliability, tangibility and assurance. In terms $\geq .05$ ).

of responsibility and empathy there was no

Table 5

One-way ANOVA for Difference between the Mean Values of the Service Dimensions

\begin{tabular}{|c|c|c|c|c|c|}
\hline RELIABILITY & Sum of squares & df & Mean square & $\mathrm{F}$ & Sig. \\
\hline Between groups & 2.723 & 1 & 2.723 & 8.989 & .003 \\
\hline Within groups & 120.538 & 398 & .303 & & \\
\hline Total & 123.260 & 399 & & & \\
\hline RESPONSIBILITY & Sum of squares & df & Mean square & $\mathrm{F}$ & Sig. \\
\hline Between groups & .106 & 1 & .106 & .207 & .649 \\
\hline Within groups & 203.214 & 398 & .511 & & \\
\hline Total & 203.319 & 399 & & & \\
\hline TANGIBILITY & Sum of squares & df & Mean square & $\mathrm{F}$ & Sig. \\
\hline Between groups & 11.223 & 1 & 11.223 & 52.348 & .000 \\
\hline Within groups & 85.325 & 398 & .214 & & \\
\hline Total & 96.548 & 399 & & & \\
\hline ASSURANCE & Sum of squares & df & Mean square & $\mathrm{F}$ & Sig. \\
\hline Between groups & 18.276 & 1 & 18.276 & 62.659 & .000 \\
\hline Within groups & 116.084 & 398 & .292 & & \\
\hline Total & 134.359 & 399 & & & \\
\hline EMPATHY & Sum of squares & df & Mean square & $\mathrm{F}$ & Sig. \\
\hline Between groups & .010 & 1 & .010 & .026 & .871 \\
\hline Within groups & 151.180 & 398 & .380 & & \\
\hline Total & 151.190 & 399 & & & \\
\hline
\end{tabular}

\section{Empirical Findings}

The author has divided this section into two segments. The first one was based on the results of the factor analysis to get the important factors affecting customer satisfaction of the public and the private banks and the second one was based on the results of multiple regressions 
applied to test the relationship between customer satisfaction and service quality of the public and the private banks. Factor analysis and Regression analysis was applied separately on the public and the private sector banks.

\section{Factor Analysis for Public Sector and Private Sector Bank}

In order to test whether the factor analysis was appropriate or not in this situation, Bartlett's test of sphericity and Kaiser-Meyer Olkin (KMO) measure of sampling adequacy were applied on the data collected for the public bank and the private sector banks.

For the public sector bank, the approximate chisquare was 4066.312 with 713 degree of freedom which was significant at 0.0001 level. Hence factor analysis was considered as an appropriate test for the analysis. For the private sector bank, the approximate chi-square value was 856.566 with 171 degrees of freedom and the KMO value (0.606) showed that the sample was good enough for sampling.

The principal component analysis model was selected to do data reduction for both the banks and only on those factors that were considered to have Eigen values greater than one. On this criteria a total of six factors emerged which accounted for 66.3 per cent of cumulative variance for PUBSB and 67.2 per cent of cumulative variance for PVTSB. The results of the principal component analysis mentioning factor loading for each factor are presented in Table 6.

\section{Table 6}

\section{Factors Affecting Customer Satisfaction}

\begin{tabular}{|c|c|c|c|c|}
\hline $\begin{array}{l}\text { Factor } \\
\text { number }\end{array}$ & $\begin{array}{l}\text { Name of } \\
\text { dimension }\end{array}$ & Statement & $\begin{array}{c}\text { Factor } \\
\text { loading } \\
\text { (PUBSB) }\end{array}$ & $\begin{array}{c}\text { Factor } \\
\text { loading } \\
\text { (PVTSB) }\end{array}$ \\
\hline \multirow[t]{3}{*}{$\mathrm{F} 1$} & \multirow{3}{*}{$\begin{array}{l}\text { Operational } \\
\text { factor }\end{array}$} & Time taken on opening account & 0.83 & 0.93 \\
\hline & & Speed of withdrawals & 0.87 & 0.90 \\
\hline & & Speed of depositing money & 0.60 & 0.62 \\
\hline \multirow[t]{3}{*}{$\mathrm{F} 2$} & \multirow{3}{*}{$\begin{array}{l}\text { Awareness } \\
\text { regarding } \\
\text { contemporary } \\
\text { services }\end{array}$} & Provide knowledge of services & 0.85 & 0.95 \\
\hline & & Bankers offer modern services & 0.77 & 0.77 \\
\hline & & Bank time-to-time intimated about new services & 0.73 & 0.78 \\
\hline \multirow[t]{3}{*}{ F3 } & \multirow[t]{3}{*}{ Price Factor } & Services charges & 0.70 & 0.40 \\
\hline & & Stability of price & 0.73 & 0.53 \\
\hline & & Price of cross-selling products & 0.73 & 0.73 \\
\hline \multirow[t]{3}{*}{ F4 } & \multirow{3}{*}{$\begin{array}{l}\text { Situational } \\
\text { factor }\end{array}$} & Location of the bank & 0.74 & 0.87 \\
\hline & & Knowledge of bank employee regarding bank services & 0.78 & 0.88 \\
\hline & & Parking facility & 0.65 & 0.65 \\
\hline
\end{tabular}




\begin{tabular}{lllcc}
\hline $\begin{array}{l}\text { Factor } \\
\text { number }\end{array}$ & $\begin{array}{l}\text { Name of } \\
\text { dimension }\end{array}$ & Statement & $\begin{array}{c}\text { Factor } \\
\text { loading } \\
\text { (PUBSB) }\end{array}$ & $\begin{array}{c}\text { Factor } \\
\text { loading } \\
\text { (PVTSB) }\end{array}$ \\
\hline F5 & $\begin{array}{l}\text { Technological } \\
\text { factor }\end{array}$ & $\begin{array}{l}\text { Computerization of the bank } \\
\text { Bank innovative services }\end{array}$ & 0.84 & 0.88 \\
& Web-based banking & 0.45 & 0.45 \\
F6 & $\begin{array}{l}\text { Satisfactory } \\
\text { relationship }\end{array}$ & Bank accords equal treatment to all customers & 0.60 & 0.62 \\
& Services helped cordial banker-customer relationship & 0.65 & 0.62 \\
\hline
\end{tabular}

The factors were named on the basis of the size of the factor loading of the variables. Factor 1, identified as "Operational Factors", was loaded with 3 variables like time taken for opening an account, speed of withdrawals and speed of deposits. Factor 2, conceptualized as " Awareness Regarding Contemporary Services", was loaded with three variables-bankers provide knowledge of services, bankers offer modern services and bank time to time intimated about new services. Factor 3, 'Price Factor' which was third on the list was loaded with three variables-service charges, stability of price, price of cross-selling. Factor 4, identified as "Situational Factors" related to location of the bank, knowledge of bank employee regarding bank services and parking facility. Factor 5, 'Technological Factor' was loaded with variables like computerization of the bank, bank innovative services and Web-based banking. Factor 6, 'Satisfactory Relationship' was loaded with two variables-bank accords equal treatment to all customers and services helped cordial banker-customer relationship.

\section{Relationship between Service Quality and Customer Satisfaction}

Multiple regression analysis was employed to examine the association between the service quality dimensions and customer satisfaction. It is a constructive statistical technique that can be used to analyse the association between a single dependent and several independent variables (Hair et al., 1998). Based on this method, the five main independent variables (service quality dimensions) and the dependent variable (customer satisfaction) were entered together. The correlations of service quality dimensions and customer satisfaction are shown in Table 7. All the correlations were positive and significant at $5 \%$; therefore it has been verified that customer satisfaction is positively related to service quality, which means better service quality leads to higher customer satisfaction.

Table 8 and Table 9, show the regression analysis of five service quality dimensions to customer satisfaction for the public sector bank and the private sector bank respectively. It can be observed that the coefficient of determination $\left(\mathrm{R}^{2}\right)$ for the public sector bank was 0.596, indicating that $59.6 \%$ of customer satisfaction can be explained by the five SERVQUAL dimensions of service quality. In the case of the private sector bank the coefficient of determination $\left(\mathrm{R}^{2}\right)$ was 0.424 , which indicated that $42.4 \%$ of customer satisfaction could be explained by the five service quality dimensions used. The proposed model was significant at $1 \%$ as the $\mathrm{p}<0.01$ was for both the public and the private sector banks. This indicated that the overall model was reasonably fit and there was a statistically significant association between the service quality dimensions and customer satisfaction. The value of coefficient of determination $\left(\mathrm{R}^{2}\right)$ indicated that customer 
satisfaction was affected by some other factors as well like: service charges, interest rates, personalized services like collecting cheques and other valuable innovative services provided by both the public and the private sector bank which explained the remaining change in customer satisfaction i.e. $40.4 \%$ in the public and $57.6 \%$ in the private sector bank. The higher value of $\left(\mathrm{R}^{2}\right)$ in the case of the public sector bank may be because of the difference in the set of innovative services offered by the private sector bank and the public sector bank and also because of the lack of awareness of the public sector bank customers about services like i-banking and mobile banking, which made them concerned more about the five service quality dimensions.

The nature of relationship the between service quality dimensions and customer satisfaction was different for the public and the private sector banks. For the public sector bank all the five service quality dimensions were found to have significant (at 5\% level) and positive effect on customer satisfaction. The individual model variables revealed that the assurance dimension with value of 0.298 was the most important as its effect on customer satisfaction was the highest followed by the reliability dimension with $\beta$ value of 0.28. Tangibles $(\beta=0.182)$, responsiveness $(\beta=$ $0.174)$ and empathy $(\beta=0.16)$ also had positive and significant effects on customer satisfaction for the public sector banks. Equation 1 shows the relationship between customer satisfaction and the five SERVQUAL service dimensions for the public sector bank.

Satisfaction of PUBSB customers $=.503+0.218$ Reliability + .102 Responsiveness + 0.166 Tangibles +0.239 Assurance +0.114 Empathy ..........Eqn 1.

Also for the private sector bank all the five service quality dimensions were found to have significant (at 5\% level) and positive effect on customer satisfaction. The individual model variables revealed that responsiveness with $\beta$ value of 0.293 was the most important as its effect on customer satisfaction was the highest followed by the assurance dimension with $\beta$ value of 0.241 and tangibles with $\beta$ value of 0.222 . Reliability $(\beta=0.168)$ and empathy $(\beta=$ 0.172 ) also had positive and significant effects on customer satisfaction for the private sector bank. Equation 2, shows the relationship between customer satisfaction and the five SERVQUAL service dimensions for the private sector bank.

Satisfaction of PVTSB customers $=0.168+$ 0.152 Reliability +0.221 Responsiveness + 0.226 Tangibles +0.200 Assurance +0.142 Empathy ..........Eqn 2.

\section{Table 7}

Correlation Coefficients between Service Dimensions and Customer Satisfaction

\begin{tabular}{lccccc}
\hline Reliability & & Responsiveness & Assurance & Empathy & Tangibles \\
\hline $\begin{array}{l}\text { Satisfaction } \\
\text { (Public sector bank) }\end{array}$ & .660 & .326 & .646 & .309 & .617 \\
$\begin{array}{l}\text { Satisfaction } \\
\text { (Private sector bank) }\end{array}$ & .316 & .469 & .402 & .304 & .410 \\
\hline
\end{tabular}

All Correlations are significant at 0.05 leve; (1-tailed). 
Table 8

Regression Results for Public Sector Bank

\begin{tabular}{|c|c|c|c|c|c|}
\hline & $\begin{array}{l}\text { Unstandardized } \\
\text { coefficients }\end{array}$ & Std. error & $\begin{array}{c}\text { Standardized } \\
\text { coefficients }\end{array}$ & T-value & Sig. \\
\hline (Constant) & .503 & .242 & & 2.082 & .039 \\
\hline Reliability & .218 & .078 & .280 & 2.798 & .006 \\
\hline Responsiveness & .102 & .047 & .174 & 2.186 & .030 \\
\hline Tangibles & .166 & .060 & .182 & 2.755 & .006 \\
\hline Assurance & .239 & .074 & .298 & 3.224 & .001 \\
\hline Empathy & .114 & .056 & .160 & 2.033 & .043 \\
\hline \multirow[t]{2}{*}{ Model summary } & $\mathrm{R}$ & $\mathrm{R}$ square & Adjusted $\mathrm{R}$ square & Std. error of the estimate & \\
\hline & .772 & .596 & .585 & .2789 & \\
\hline
\end{tabular}

Table 9

Regression Results for the Private Sector Bank

\begin{tabular}{|c|c|c|c|c|c|}
\hline & $\begin{array}{l}\text { Unstandardized } \\
\text { coefficients }\end{array}$ & Std. error & $\begin{array}{l}\text { Standardized } \\
\text { coefficients }\end{array}$ & T-value & Sig. \\
\hline (Constant) & .168 & .406 & & .415 & 679 \\
\hline Reliability & .152 & .060 & .168 & 2.521 & .013 \\
\hline Responsiveness & .221 & .055 & .293 & 4.014 & .000 \\
\hline Tangibles & .226 & .061 & .222 & 3.731 & .000 \\
\hline Assurance & .200 & .053 & .241 & 3.761 & .000 \\
\hline Empathy & .142 & .059 & .172 & 2.428 & .016 \\
\hline \multirow[t]{2}{*}{ Model Summary } & $\mathrm{R}$ & R Square & Adjusted R Square & $\begin{array}{l}\text { Std. Error of the } \\
\text { Estimate }\end{array}$ & \\
\hline & .651 & .424 & .409 & .3172 & \\
\hline
\end{tabular}

\section{Conclusion}

The present study made an attempt to analyse the level of customer awareness, customer's experience about SERVQUAL service dimensions of a public and a private sector bank and its impact on customer satisfaction. The results revealed that the private sector bank dominated the public sector bank in terms of providing awareness and delivering quality services. The Z-test results revealed that the customers of the private sector bank had a higher degree of awareness for services like mobilebanking, i-banking and phone banking.

The one-way ANOVA test which was done to compare the service quality of the public and the private sector banks revealed that the private sector bank was better than the public sector bank in the service dimensions of reliability, tangibility and assurance, whereas in terms of responsibility and empathy no difference was found between the two sector banks. 
The analysis of regression on the five dimensions of service quality with customer satisfaction was significant for all the service dimensions. In particular, customers of the public sector bank indicated high satisfaction with reliability and assurance, whereas customers of the private sector bank indicated high satisfaction with responsiveness, tangibles and assurance.

The correlation between reliability and customer satisfaction was highest followed by assurance in the case of the public sector bank, which implies that improvement in employees' reliability and assurance is an important issue that requires the attention of the Indian public sector banks. Similarly, for the private sector banks responsiveness and assurance are important for improving their customer satisfaction. This finding reinforces the need for bank managers to place emphasis on the underlying dimensions of service quality, especially on assurance, and should start with improving service quality in order to elevate customer satisfaction.

The study is consistent with prior research (Saravan and Rao, 2007) in concluding that service quality is a significant determinant of customer satisfaction, and service quality is the vital factor that affects customer satisfaction. Therefore, banks should be consistent in providing high quality service in order to retain and increase their customer base. Increase in service quality will improve customer satisfaction level and banks will be able to maintain a stable customer base.

The result also revealed that although the private sector bank is new as compared to the public sector bank it is competing successfully with the public sector bank and is building efforts to offer better banking services in tune with the changing global business environment.

\section{Managerial Implications}

The findings of the study have important implications for managers of the Indian commercial banks in terms of service quality that should be provided and its significant influence on the customer satisfaction. In particular, managers of the public sector banks should be aware that, they should adapt the latest technologies and they should also increase their customers' awareness level about the services offered.

Assurance emerged as the important dimension both in the public and the private sector bank in fostering satisfaction among the customers of the Indian commercial banks. It was evident that the satisfactions of the customers was significantly influenced by reliability, assurance, responsiveness and up to some extent by tangibles but empathy least affected customer satisfaction. It is thus evident that managers of Indian commercial banks should assess and monitor the service quality of the banks periodically, to enable the banks to identify where improvements are needed from the customers' viewpoint, and to place emphasis on the underlying dimensions of service quality, especially on assurance, reliability and responsiveness and should start with improving service quality in order to elevate customer satisfaction.

Banks should also have a strong customer relationship management system that would keep them informed about their customers' expectations and changing needs. The private sector banks are front runners in this regard when compared to the public sector banks. For the public sector banks, the skills of the employees need to be enhanced so as to make them more comfortable with the latest technologies. They should also run some customer awareness programmes as these will also lead to customer satisfaction.

\section{References}

Bahia, K., \& Nantel, J. (2000). A reliable and valid measurement scale for the perceived service quality of banks. The International Journal of Bank Marketing, 18(2), 84-91. 
Banerjee, A. V. (2005). Bank competition in India. Working Paper Stanford Centre for International Development, Stanford University.

Bhat, M.A. (2005). Correlates of service quality in banks; An empirical investigation. Journal of Services Research, 5(1), 77 91.

Bolton, R. N., \& Drew, J.H. (1991). A multistage model of customers' assessments of service quality and value. Journal of Consumer Research, 17(2), 375-384.

Brady, M.K., \& Cronin, J. J. Jr. (2001). Some new thoughts on conceptualizing perceived service quality: A hierarchical approach. Journal of Marketing, 65, 34-49.

Carlo, G. I. et al. (2005). Service quality in banks: Insights from the Brazilian experience. Journal of Internet Banking and Commerce, 10(3).

Chakrabarti, R. (2005). Banking in India-reforms and reorganization. Working paper Indian School of Business, India. Available at http://papers.ssrn.com/

Cronin, J. J., \& Taylor, S. A. (1994). SERVPERF versus SERVQUAL: Reconciling performancebased and perception-minus-expectations measurement of service quality. Journal of Marketing, 58(1),125-31.

Cronin., J. Joseph., \& Taylor, S. A. (1992). Measuring service quality: A reexamination and extension. Journal of Marketing, 56, $55-68$

Dhade, A., \& Mittal, M. (2008). Preferences, satisfaction level and chances of shifting : A study of the customers of public sector and new private sector banks. ICFAI University Journal of Bank Management, 7(2), 62-74.

Gronroos, C. (1984). A service quality model and its marketing implications. European Journal of Marketing, 18(4), 36-44.

Hair, J. F. Jr., Anderson, R. E., Tatham, R. L., \& Black, W. C. (1998). Multivariate data analysis $\left(5^{\text {th }}\right.$ ed.). Upper Saddle River, NJ: Prentice Hall.

Jabnoun, N., Hussein A., \& Al-Tamimi, H. (2003). Measuring perceived service quality at UAE commercial banks. International Journal of Quality \& Reliability Management, 20(4), 458-472.

McAlexander., James, H., Dennis, K., \& Harold, K. (1994). Measurement and assessment of service quality in a health care setting. Journal of Health Care Marketing, 14(Fall), 34-41.

Mihelis, G., Grigoroudis, E., Siskos, Y., Politis, Y., \& Malandrakis, Y. (2001). Customer satisfaction measurement in the private bank sector. European Journal of Operational Research, 130(2), 347-60.

Parasuraman, A., Zeithaml, V. A., \& Berry, L. L. (1985). A conceptual model of service quality and its implications for future research. Journal of Marketing, 49(4), 41-51.

Parasuraman, A., Zeithaml, V. A., \& Berry, L. L. (1988). SERVQUAL: A multiple-item scale for measuring consumer perceptions of service quality. Journal of Retailing 64(1), 12-37.

Popli, G. S., \& Rao, D. N. (2009). Customer relationship management in Indian banks. Social Science Research Network.

Ravichandran, K., Tamil Mani, B., Arun Kumar, S., \& Prabhakaran, S. (2010). Influence of service quality on customer satisfaction - Application of SERVQUAL Model. International Journal of Business and Management, 5(4), 117-124.

Rust, R. T., \& Oliver, R. L. (1994). Service quality: New directions in theory and practice. Thousand Oaks, California: SAGE Publication.

Saneyei, A. (2008). Customer satisfaction in Irani banking system. International Journal of Banking \& Commerce, 11(3), 7-19.

Santos, U.V.(2002). Analysis of service quality in the hospitality industry using the SERVQUAL Model. Harvard Business Review, 69,71-81.

Saravanan, R., \& Rao, K. S. P. (2007). Measurement of service quality from the customer's perspective - An empirical study. Total Quality Management, 18(4), 435-449. 
Sathye, M. (2003). Efficiency of banks in a developing economy: The case of India. European Journal of Operational Research, 148, 662-671.

Seth, N., \& Deshmukh, S. J. (2005). Service quality models: A review. International Journal of Quality \& Reliability Management, 22(9), 913-949.

Siddiqi, K. M. (2011). Interrelations between service quality attributes, customer satisfaction and customer loyalty in the retail banking sector in Bangladesh. International Journal of Business Management, 6(3), 12-36.

Singh, S. (2008). A study of the quality of services provided to SSI customers by public sector banks. ICFAI University Journal of Bank Management, 7(3), 7184.

Sureshchandar, G. S., Chandrashekharan, R., \& Anantharaman, R. N. (2002). The relationship between service quality and customer satisfaction: A factor specific approach. Journal of Services Marketing, 16(4), 363-379.

Taylor, S. A., \& Baker, T. L. (1994). An assessment of the relationship between service quality and customer satisfaction in the formation of consumers' purchase intentions. Journal of Retailing, 70(2), 163-78.

Zeithaml, V. A., \& Bitner, M. J. (2000). Services marketing - Integrating customer focus across the firm. New York: McGrawHill.

Zeithaml, V. A., Berry, L. L., \& Parasuraman, A. (1996). The behavioral consequences of service quality. Journal of Marketing, $60,31-46$.

Zeithaml, V. A., Berry, L. L., \& Parsuraman, A. (1993). The nature and determinants of expectations of service. Journal of the Academy of Marketing Science, 21, $1-12$ 
